\title{
Analisis faktor-faktor yang mempengaruhi pendapatan rumah tangga miskin di Kabupaten Tanjung Jabung Barat (studi kasus di Desa Semau Kecamatan Bram Itam)
}

\author{
Ahmad Rafii *; Yulmardi; Adi Bhakti \\ Prodi Ekonomi Pembangunan Fak. Ekonomi dan Bisnis Universitas Jambi \\ *E-mail korespondensi: rafiahmad7336@gmail.com
}

\begin{abstract}
The research aims to 1). Knowing the socioeconomic characteristics of poor households 2). Knowing the effect of working hours, education, age, and land area on the income of poor households in Semau Village, Bram Itam District, Tanjung Jabung Barat Regency. The research used descriptive analysis method and quantitative analysis with multiple linear regression analysis. Based on the results of the analysis of the characteristics of poor households in Semau villages, dominated by the age of 15-64 years (61.01\%), the work of farmers (53.22\%), the average income is IDR 650,000 (41-9\%), work 180-230 hours (61.29\%), education level did not complete elementary school (43.5\%), age > 50 years $(53.2 \%)$, land area (64.5\%). Simultaneously the outpouring of working hours, education, age, and land area have a significant effect, partially education and land area have a positive and significant effect, the number of working hours and age do not have a significant effect on the income of poor households in Semau Village, Bram Itam District, Tanjung Jabung Barat Regency.
\end{abstract}

Keywords: Socio-economic characteristics, Income, Work hours expenditure, education, Age, Land area

\begin{abstract}
Abstrak
Penelitian bertujuan untuk 1).Mengetahui karakteristik sosial ekonomi rumah tangga miskin 2).mengetahui pengaruh curahan jam kerja, pendidikan, usia dan luas lahan terhadap pendapatan rumah tangga miskin di Desa Semau Kecamatan Bram Itam Kabupaten Tanjung Jabung Barat. Penelitian menggunakan Metode analisis deskriptif dan analisis kuantitatif dengan analisis regresi linier berganda. Berdasarkan hasil analisis karekteristik rumah tangga miskin didesa semau,didominasi usia 15-64 tahun $(61,01 \%)$, pekerjaan petani $(53,22 \%)$, jumlah pendapatan rata-rata $\mathrm{Rp} 650.000$,(41-9\%), curahan jam kerja 180-230 jam(61,29\%), tingkat pendidikan tidak tamat $\mathrm{SD}(43,5 \%)$, usia $>50$ tahun(53,2\%), luas lahan(64,5\%). Secara simultan curahan jam kerja, pendidikan, usia, dan luas lahan berpegaruh signifikan, secara parsial pendidikan dan luas lahan berpengaruh positif dan signifikan, curaha jam kerja dan usia tidak berpengaruh signifikan terhadap pendapatan rumah tangga miskin di Desa Semau Kecamatan Bram Itam Kabupaten Tanjung Jabung Barat.
\end{abstract}

Kata kunci: Karateristik sosial ekonomi, Pendapatan, Curahan jam kerja, Pendidikan, Usia, Luas lahan.

\section{PENDAHULUAN}

Kemiskinan merupakan masalah sosial yang bersifat global dan menjadi perhatian banyak orang di seluruh dunia. Kemiskinan tidak hanya dijumpai di suatu daerah, tempat atau negara tertentu. Akan tetapi, hampir di setiap belahan dunia dan di negara manapun, kemiskinan akan selalu dijumpai sebagai suatu permasalahan sosial yang kompleks. Kemiskinan juga dapat dikatakan sebagai permasalahan kemanusiaan yang dapat menghambat kesejahteraan dan kemajuan peradaban. 
Indonesia telah memberi perhatian khusus terhadap pentingnya pengentasan kemiskinan. Dalam UU No.11 tahun 2009 tentang kesejahteraan sosial menyatakan bahwa kemiskinan merupakan salah satu kriteria masalah sosial dalam penyelenggaraan kesejahteraan sosial. Kemiskinan juga 2 dijelaskan Perpres No.2 tahun 2015 tentang Rencana Pembangunan Jangka Menengah Nasional(RPJMN), yaitu dalam misi RPJMN mewujudkan pemerataan pembangunan dan berkeadilan salah satunya dengan menanggulangi kemiskinan. Hal ini dapat diartikan bahwa kemiskinan mempunyai peran penting dalam pembangunan ekonomi suatu negara.

Peningkatan kesejahteraan rakyat salah satu indikatornya adalah penurunan tingkat kemiskinan. Berbagai upaya terus diarahkan untuk mengejar target tingkat kemiskinan sebesar 7,00-8,00 persen yang ingin dicapai pada akhir RPJMN 2015- 2019. Dalam enam bulan terakhir yaitu periode September 2016 - Maret 2017, persentase penduduk miskin menurun sebesar 0,04 persen dari 10,70 persen (September 2016) menjadi 10,64 persen (Maret 2017). Adanya kenaikan jumlah penduduk, secara absolut jumlah penduduk miskin meningkat sekitar 6,90 ribu dari 27,76 juta jiwa pada September 2016. Jika dihitung dari periode yang sama pada tahun sebelumnya (Maret 2016) jumlah penduduk miskin berkurang sekitar 0,24 juta jiwa yaitu dari 28,01 juta jiwa pada Maret 2016 menjadi 27,77 juta jiwa pada Maret 2017.

Kabupaten Tanjung Jabung Barat yang dengan jumlah penduduk 310.914 jiwa juga menunjukan kondisi yang tidak jauh berbeda. Sebagaian besar daerah ini juga masih mengandalkan sektor pertanian yang memberikan kontribusi yang cukup besar terhadap Produk Domestik Regional Bruto(PDRB) Kabupaten Tanjung Jabung Barat sektor pertanian. Yaitu sektor pertanian pada tahun 2009 sebesar Rp. 1.394.371,meningkat ditahun 2010 sebesar Rp. 1.981.138,- dan terus mengalami peningkatan pada tahun 2013 menjadi sebesar Rp. 3.113.288,- juta (BPS, 2014).

Sebagai salah satu daerah di Kabupaten Tanjung Jabung Barat, Desa Semau Kecamatan BramItam Kabupaten Tanjung Jabung Barat juga menghadapi fenomena yang sama dengan daerah-daerah lainnya. Jumlah rumah tangga miskin tahun 2018 dari 223 Kepala keluarga, dimana persentase penduduk miskin di Desa Semau yang berjumlah 3.6\% kepala keluarga yang masih dinyatakan miskin.

\section{METODE}

\section{Jenis penelitian}

Jenis dan sumber data yang digunakan dalam penelitian ini diambil melalui teknik wawancara atau bertanya langsung kuisioner pada responden yang berberdomisili di Desa Semau Kecamatan Bram Itam Kabupaten Tanjab Barat sebanyak 62 kepala keluarga.

\section{Populasi dan sampel}

Populasi adalah wilayah generalisasi yang terdiri dari atas objek yang mempunyai kualitas dan karateristik tertentu yang diterapkan oleh peneliti untuk dipelajari dan kemudian ditarik kesimpulannya(Sugiyono,2013). Populasi adalah seluruh objek dengan karateristik tertentu dalam suatu penilitian. Adapun populasi dalam penelitian ini adalah dimana para kelurga rumah tangga miskin Desa Semau yang berjumlah 62 kepala keluarga.

\section{Analisis regresi linier berganda}

Untuk mengetahui pengaruh Jumlah jam kerja, pendidikan, usia terhadap tingkat kemiskinan di Desa semau, digunakan analisis regresi linier berganda menurut Supranto (2001:189) :

$Y=\beta_{0}+\beta_{1} X_{1}+\beta_{2} X_{2}+\beta_{3} X_{3}+\beta_{4} X_{4}+e$ 


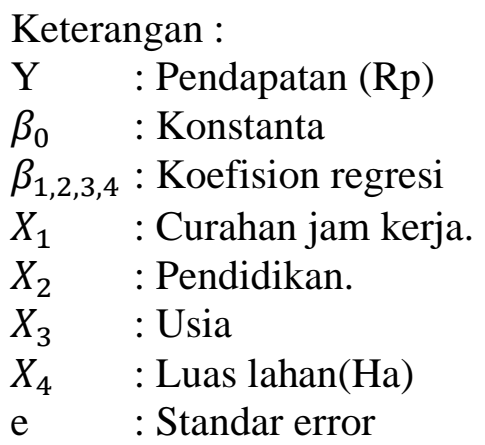

\section{Uji statistik}

\section{Uji F}

Uji $\mathrm{F}$ atau secara simultan pada dasarnya digunakan untuk menunjukan apakah semua variabel bebas yaitu curahan jam kerja, pendidikan, usia, luas lahan yang dimaksukan dalam model mempunyai pengaruh secara bersama-sama terhadap variabel terikat yaitu pendapatan, nilai uji $\mathrm{F}$ ditentukan menggunakan tabel distribusi normal dengan tingkat signifikansi 5\% dan derajat kebebasan dengan rumus $(\mathrm{k} ; \mathrm{n}-\mathrm{k})$.

Bila t hitung < dari t tabel maka Ho ditolak dan Ha diterima artinya secara individual variabel jam kereja, pendidikan, usia dan luas lahan berpengaruh signifikan terhadap pendapatan rumah tangga miskin di Desa Semau kec. Bram Itam.

Bila $t$ hitung $>$ dari $t$ tabel maka Ho diterima dan Ha ditolak. Artinya secara individual jam kerja, pendidikan, usia dan luas lahan tidak berpegaruh terhadap pendapatan rumah tangga miskin di Desa Semau kec. Bram Itam.

\section{Uji t}

Uji t atau secara parsial pada dasarnya digunakan untuk menunjukkan ada atau tidaknya pengaruh variabel bebas yaitu curahan jam kerja, pendidikan, usia dan luas lahan secara individual terhadap variabel terikat yaitu pendapatan. Untuk melihat hasil uji t atau secara parsial, Nilai dalam uji t ditentukan menggunakan tabel distribusi normal dengan tingkat signifikan 5\% dan derajat kebebasan dengan rumus (a/2;n-k-1).

Bila $\mathrm{t}$ hitung $>$ dari $\mathrm{t}$ tabel maka Ho ditolak dan $\mathrm{Ha}$ diterima artinya secara individual variabel jam kereja, pendidikan, usia dan luas lahan berpengaruh signifikan terhadap pendapatan rumah tangga miskin di Desa Semau kec. Bram Itam.

Bila t hitung < dari t tabel maka Ho diterima dan Ha ditolak. Artinya secara individual jam kerja, pendidikan, usia dan luas lahan tidak berpegaruh terhadap pendapatan rumah tangga miskin di Desa Semau kec. Bram Itam.

\section{Koefisien determinasi $\left(\mathbf{R}^{2}\right)$}

Koefisien determinasi $\left(\mathrm{R}^{2}\right)$ digunakan untuk melihat seberapa besar variabelvariabel independen secara bersama mampu memberikan penjelasan mengenai variabel terikat. Nilai koefisien determinasi $\left(\mathrm{R}^{2}\right)$. Koefisien determinasi $\left(\mathrm{R}^{2}\right)$ bernilai 0 berarti tidak ada hubungan antara variabel -variabel bebas dengan variabel terikat, sebaliknya koefisien determinasi $\left(\mathrm{R}^{2}\right)$ bernilai 1 berarti ada hubungan sempurna antara variabel bebas dengan variabel terikat.

\section{Uji normalitas}

Uji normalitas bertujuan untuk menguji residual model regresi yang dibuat apakah berdistribusi normal atau tidak. Model regresi yang baik adalah yang memiliki distribusi 
normal atau mendekati normal, terpenuhi atau tidaknya uji normalitas dapat diuji dengan melakukan uji statistik Jerque-Bera.

\section{Uji asumsi klasik}

\section{Uji multikolineritas}

Uji multikonlineritas digunakan untuk menentukan dan mengetahui ada tidaknya hubungan dua atau lebih variabel yang saling berkaitan dalam suatu model. Multikolineritas terjadi apabila terdapat nilai koefisien variabel diluar batas-batas penerimaan dan sebaliknya apabila nilai-nilai koefisien korelasi terletak didalam batasbatas penerimaan maka tidak akan terjadi multikolineritas.

\section{Uji autokorelasi}

Uji autokorelasi digunakan untuk memenuhi ada atau tidaknya penyimpangan asumsi klasik autokorelasi, yaitu korelasi yang terjadi antara residual pada satu pengamatan dengan pengamatan lain pada model regresi. Metode pengujian yang sering digunakan adalah dengan uji Breusch-GodfreySerial Correlation LM Test.

\section{Uji heterokedestisitas}

Uji heterokedestisitas digunakan untuk melihat apakah ada ketidaksamaan varian dari residuel untuk pengamatan pada model regresi berganda. Apbila asumsi heterokedestisitas tidak terpenuhi maka model regresi dinyatakan tidak valid.

\section{HASIL DAN PEMBAHASAN}

\section{Karateristik sosial ekonomi rumah tangga miskin}

Pada bagian ini dikemukan berbagai karateristik sosial ekonomi remah tangga miskin di Desa Semau kecamatan Bram itam kab. Tanjab Barat. Responden yang digunakan ini adalah sebagian dari hasil sensus dari wilayah kantor Desa Semau yang masih tinggal dalam wilayah sekitar. Dan kembali di lakukan melalui kuisioner yang dilakukan melalui penulitian ini. Karakteristik responden yang diteliti dalam penelitian meliputi curah jam kerja, pendidikan, usia, dan luas lahan.

\section{Pendapatan}

Berdasarkan hasil pengisisn angket/kuesioner dengan para rumah tangga miskin di Desa Semau, berikut ini adalah pendapatan per minggu responden berdasarkan hasil pendapatan/penghasilan dalam perbulannya:

Berdasarkan Tabel.1 diatas, sebagian besar pendapatan rumah tangga responden Rp 500.100 - Rp 800.000 sebanyak 26 orang(41,9\%), sedangkan sebagian dari Rp 300.100 - Rp 500.000 sebanyak 24 orang(38,8\%), Rp100.000 - Rp 300.000 sebanyak 12 orang $(19,3 \%)$.

Tabel 1. Jumlah dan persentase rumah tangga miskin Desa Semau Kecamatan Bram Itam berdasarkan pendapatan responden

\begin{tabular}{cccc}
\hline No & Pendapatan & Jumlah & Persentase(\%) \\
\hline 1 & Rp 100.000 - Rp 300.000 & 12 & 19,3 \\
2 & Rp 300.100 - Rp 500.000 & 24 & 38,8 \\
3 & Rp 500.100 - Rp 800.000 & 26 & 41,9 \\
4 & $>$ Rp 800.000 & 0 & 0 \\
\hline & Jumlah & $\mathbf{6 2}$ & $\mathbf{1 0 0 , 0 0}$ \\
\hline
\end{tabular}

Sumber : Data diolah, 2019 


\section{Curahan jam kerja}

Berdasarkan hasil penelitian di Desa Semau kec. Bram Itam, Curahan Jam Kerja terendah adalah $20 \mathrm{jam} / \mathrm{minggu}$, dan jam kerja tertinggi adalah $42 \mathrm{jam} / \mathrm{minggu}$. Ratarata jam kerja responden di Desa Semau Kecamatan Bram Itam.

Tabel 2. Jumlah dan persentase rumah tangga miskin Desa Semau Kecamatan Bram Itam berdasarkan curahan jam kerja

\begin{tabular}{|c|c|c|c|}
\hline No & Curahan Jam Kerja & Jumlah & Persentase $(\%)$ \\
\hline 1 & $150-179$ & 15 & 24,19 \\
\hline 2 & $180-230$ & 38 & 61,29 \\
\hline \multirow[t]{3}{*}{3} & $240-400$ & 9 & 14,52 \\
\hline & Jumlah & 62 & 100,00 \\
\hline & Rata-Rata & \multicolumn{2}{|c|}{208 Jam } \\
\hline
\end{tabular}

\section{Sumber : Data diolah, 2019}

Dari Tabel.2 diatas dapat diketahui bahwa jam kerja terendah rumah tangga miskin didesa semau kec.bram itam berkisar antara 150-170 jam sebanyak 15 orang atau sebesar $24,19 \%$ sedangkan rumah tangga miskin yang memiliki jam kerja tertinggi yaitu 240-400 jam sebanyak 9 orang atau sebesar 14,52\% dan rumah tangga miskin yang memiliki jam kerja sedang sebanyak 38 orang atau sebesar $61,29 \%$ dengan ratarata jam kerja perbulan sebesar 208 jam perbulan.

\section{Tingkat pendidikan}

Tingkat pendidikan diukur dengan menghitung tahun sukses pendidikan responden berada rentang antara dengan rata-rata tahun sukses pendidikan.

Berdasarkan Tabel.3 diatas sebagian besar responden memiliki tingkat pendidikan cukup bersekolah tidak sampai menyelesaikan tingkat SD sebanyak 27 orang(43,5\%), sedangkan yang yang menyelesaikan/tamat SD 20 orang $(32,2 \%)$, sedangkan yang tamatan SMP 11 orang $(17,7 \%)$, dan sebanyak 4 orang $(6,4 \%)$ responden mempunyai tingkat pendidikan yang tinggi.Berikut ini adalah persentase responden berdasarkan tingkat pendidikannya:

Tabel 3. Jumlah dan persentase rumah tangga miskin Desa Semau Kecamatan Bram Itam berdasarkan pendidikan responden

\begin{tabular}{cccc}
\hline No & Pendidikan & Jumlah & Persentase(\%) \\
\hline 1 & Tidak tamat SD & 27 & 43,5 \\
2 & Tamat SD & 20 & 32,2 \\
3 & Tamat SMP & 11 & 17,7 \\
4 & Tamat SMA & 4 & 6,4 \\
\hline 5 & Jumlah & $\mathbf{6 2}$ & $\mathbf{1 0 0 , 0 0}$ \\
\hline
\end{tabular}

Sumber: Data diolah, 2019

Usia

Berdasarkan hasil angket/kuesioner dengan para rumah tangga miskin di Desa Semau Kecamatan Bram Itam, berikut ini adalah persentase responden berdasarkan usia: 
Tabel 4. Jumlah dan persentase rumah tangga miskin Desa Semau Kecamatan Bram\ Itam berdasarkan usia responden

\begin{tabular}{ccc}
\hline Usia & Jumlah & Persentase(\%) \\
\hline 25 - 30 Tahun & 3 & 2.0 \\
$31-40$ Tahun & 11 & 17.7 \\
$41-50$ Tahun & 15 & 24.1 \\
$>$ 50 Tahun & 33 & 53.2 \\
\hline Jumlah & $\mathbf{6 2}$ & $\mathbf{1 0 0 , 0 0}$ \\
\hline Rata-Rata & $\mathbf{> 5 0}$ \\
\hline
\end{tabular}

Sumber : Data diolah, 2019

Berdasarkan Tabel.4 diatas, sebagian besar responden berumur lebih dari 50 tahun keatas yaitu sebanyak 33 responden(53,2\%), sedangkan sisanya berumur 25-30 tahun sebanyak 3 orang(2,0\%), berumur 31-40 tahun sebanyak 11 orang $(17,1 \%)$, dan pada umuran 41-50 tahun 15 orang $(24,1 \%)$, dengan rata-rata kelompok umur $>50$ tahun yang mendominasi.

\section{Beban tanggungan}

Beban tanggungan yang dimaksud dalam penelitian ini adalah anggota keluarga yang menjadi tanggung jawab dari setiap kepala rumah tangga. Berdasarkan Tabel.5 diatas diketahui bahwa rumah tangga miskin desa semau kec.bram itam memiliki beban tanggungan 6 orang sebanyak 2atau sebesar 3,22\%, rumah tangga miskin yang memiliki beban tanggungan 2 0rang sebanyak 18 orang atau sebesar $29,03 \%$ dan sedangkan rumah tangga miskin yang memiliki beban tanggungan 1 orang sebanyak 13 orang atau sebanyak 20,97\% untuk yang tidak memiliki tanggungan karena telah ditinggal pergi suami atau istri meninggal dunia sebanyak 9 orang atau sebasar 14,52\%. Untuk mengetahui beben tanggungan kepala rumah tangga di Desa Semau kecamatan Bram Itam dapat dilihat dalam tabel berikut :

Tabel 5. Jumlah dan persentese rumah tangga miskin Desa Semau Kecamatan Bram Itam berdasarkan beban tanggungan

\begin{tabular}{cccc}
\hline No & Beban Tanggungan(oranag) & Jumlah & Persentase(\%) \\
\hline 1 & Tidak ada & 9 & 14,52 \\
2 & 1 & 13 & 20,97 \\
3 & 2 & 18 & 29,03 \\
4 & 3 & 10 & 16,12 \\
5 & 4 & 5 & 8,07 \\
6 & 5 & 5 & 8,07 \\
7 & 6 & 2 & 3,22 \\
\hline \multicolumn{3}{c}{} \\
\hline
\end{tabular}

Sumber: Data diolah, 2019

\section{Pekerjaan}

Pekerjaan ini status yang dimaksud dalam penelitian ini adalah status pekerjaan dari rumah tangga miskin Desa Semau Kecamatan Bram Itam. dilihat dalam tabel berikut : 
Tabel 6. Jumlah dan persentase rumah tangga miskin Desa Semau Kecamatan Bram Itam berdasarkan jenis pekerjaan

\begin{tabular}{cccc}
\hline No & Pekerjaan & Jumlah & Persentasre\% \\
\hline $\mathbf{1}$ & Pedagang & 5 & 8,07 \\
$\mathbf{2}$ & Pertukangan & 14 & 22,59 \\
$\mathbf{3}$ & Petani & 33 & 53,22 \\
$\mathbf{4}$ & Buruh & 10 & 16,12 \\
\hline & Jumlah & $\mathbf{6 2}$ & $\mathbf{1 0 0 , 0 0}$ \\
\hline
\end{tabular}

Sumber : Data diolah, 2019

Berdasarkan Tabel.6 diatas maka dapat dijelaskan bahwa dari 62 rumah tangga miskin desa semau kec.bram itam ternyatan sebagian besar pekerjan terdapat pada pertanian yang berjumlah 33 orang atau sebesar 53,22\%, pertukangan sebanyak 14 orang sebesar $22,59 \%$ dan sedangkan buruh dan pedagang sebanyak 10 dan 5 orang sebanyak $16,12 \%$ dan $8,07 \%$.

\section{Luas lahan}

Luas lahan yang dimaksud dalam penelitian ini adalah luas lahan yang dimiliki dari rumah tangga miskin desa semau kec.bram itam. Berdasarkan Tabel.7 maka dapat diketahui bahwa rumah tangga miskin desa semau kec.bram itam sebagian besar memiliki luas lahan $0.25-0.50$ sebanyak 20 orang atau sebesar $32,25 \%$ dan dibawah dari itu seluas $0.10-0.25$ sebanyak 20 orang sebesar $32,25 \%$ dan adapun yang memiliki luas lahan yang lebih besar \pm 1 Ha sebanyak 8 orang sebesar $12,93 \%$ dan beberapa rumah tangga miskin yang tidak memiliki luas lahan sebanyak 4 orang sebesar $6,45 \%$ itu lahan yang dimiliki hanyalah rumah tempat tinggal, sebagian lahan-lahan yang dimailiki hanyalah lahan pertanian yang digarap sebagi lahan sewa lahan yang dimiliki orang lain yang dibayar dengan berhasil atau tidak berhasilnya hasil pertanian.

Untuk mengetahui luas lahan yang dimiliki dalam satuan hektar, berapa luas lahan yang dimiliki rumah tangga miskin Desa Semau Kecamatan Bram Itam dapat dilihat dalam tabel berikut :

Tabel 7. Jumlah dan persentase rumah tangga miskin Desa Semau Kecamatan Bram Itam berdasarkan luas lahan

\begin{tabular}{cccc}
\hline No & Luas Lahan & Jumlah & Persentase\% \\
\hline $\mathbf{1}$ & Tidak ada & 4 & 6.45 \\
$\mathbf{2}$ & $0-0.10$ & 10 & 16.12 \\
$\mathbf{3}$ & $0.11-0.25$ & 20 & 32.25 \\
$\mathbf{4}$ & $0.26-0.50$ & 20 & 32.25 \\
$\mathbf{5}$ & $0.51-1 \mathrm{Ha}$ & 5 & 8.1 \\
$\mathbf{6}$ & $>1 \mathrm{Ha}$ & 3 & 4.83 \\
\hline & Jumlah & $\mathbf{6 2}$ & $\mathbf{1 0 0 , 0 0}$ \\
\hline
\end{tabular}

Sumber : Data diolah, 2019

\section{Regresi linier berganda}

Pengolah data dengan menggunakan eviews 9.0 untuk melihat pengaruh variabel curah jam kerja, pendidikan, usia, dan luas lahan terhadap pendapatan rumah tangga miskin di desa semau kec.bram itam menghasilkan output berikut : 
Tabel 8. Hasil regresi linier berganda

\begin{tabular}{lrccc}
\hline \hline \multicolumn{1}{c}{ Variable } & Coefficient & Std. Error & t-Statistic & Prob. \\
\hline \hline C & 1.628818 & 0.958573 & 1.699212 & 0.0947 \\
Curahan jam kerja & 0.005829 & 0.010551 & 0.552502 & 0.5828 \\
Pendidikan & 0.054801 & 0.022211 & 2.467224 & 0.0166 \\
Usia & -0.008699 & 0.008004 & -1.086758 & 0.2817 \\
Luas lahan & 1.297671 & 0.361849 & 3.586220 & 0.0007 \\
\hline \hline & 0.504353 & Mean dependent var & 2.095935 \\
R-squared & 0.469571 & S.D. dependent var & 0.687516 \\
Adjusted R-squared & 0.500722 & Akaike info criterion & 1.531674 \\
S.E. of regression & 14.29116 & Schwarz criterion & 1.703217 \\
Sum squared resid & -42.48189 & Hannan-Quinn criter. & 1.599026 \\
Log likelihood & 14.50032 & Durbin-Watson stat & 2.441234 \\
F-statistic & 0.000000 & & & \\
Prob(F-statistic) & & & & \\
\hline \hline
\end{tabular}

Sumber : Data diolah, 2019

Dari perolehan model regresi linier berganda pada Tabel.8 diatas dapat dilihat bahwa tanda koefisien estimasi kontanta sebesar (1.628818) atau bertanda positif Artinya , jika curahan jam kerja, pendidikan, usia dan luas lahan sama dengan nol, maka pendapatan rumah tangga miskin di desa semau kec.bram itam kab.tanjab barat yang didapat sebesar Rp 1.628.818.

Dapat dilihat bahwa tanda koefisien regresi curahan jam kerja sebesar (0.005829) atau bertanda positif Artinya, jika variabel lain sama dengan nol, maka kenaikan 1 jam curahan jam kerja maka pendapatan rumah tangga miskin di desa semau kec.bram itam kab.tanjab barat mengalami peningkatan sebesar Rp 0,005,829.

Dapat dilihat bahwa tanda koefisien regresi pendidikan sebesar (0.054801) atau bertanda positif Artinya, jika variabel lain sama dengan nol, maka kenaikan 1 tahun pendidikan maka pendapatan rumah tangga miskin di desa semau kec.bram itam kab.tanjab barat mengalami peningkatan sebesar Rp 0,054,801.

Dapat dilihat bahwa tanda koefisien regresi usia sebesar (-0.008699) atau bertanda negatif Artinya, jika variabel lain sama dengan nol, maka kenaikan 1 tahun usia maka pendapatan rumah tangga miskin di desa semau kec.bram itam kab.tanjab barat mengalami pengurangan sebesar Rp -0,008,699.

Dapat dilihat bahwa tanda koefisien regresi luas lahan sebesar (1.297671) atau bertanda positif Artinya , jika variabel lain sama dengan nol, maka kenaikan 1 hektar pendidikan maka pendapatan rumah tangga miskin di desa semau kec.bram itam kab.tanjab barat mengalami peningkatan sebesar Rp 1,297,671.

\section{Uji statistik}

\section{Uji simultan (Uji F)}

Uji $\mathrm{F}$ atau secara simultan pada dasarnya digunakan untuk menunjukan apakah semua variabel bebas yaitu curahan jam kerja, pendidikan, usia, luas lahan yang dimaksukan dalam model mempunyai pengaruh secara bersama-sama terhadap variabel terikat yaitu pendapatan, nilai uji $\mathrm{F}$ ditentukan menggunakan tabel distribusi normal dengan tingkat signifikansi $5 \%$ dan derajat kebebasan dengan rumus (k;n-k). menunjukkan bahwa untuk pengaruh variabel curahan jam kerja, pendidikan, usia dan 
luas lahan secara simultan terhadap variabel pendapatan adalah $0,000<0,05$ atau dengan tingkat signifikan 5\% dan nilai $\mathrm{F}_{\text {hitung }} 1.450032<\mathrm{F}$ tabel 3,16, sehingga dapat disimpulkan maka $\mathrm{H} 0$ ditolak. Ini menunjukan terdapat pengaruh variabel curahan jam kerja, pendidikan, usia, dan luas lahan secara simultan terhadap pendapatan rumah tangga miskin di desa semau kec.bram itam kab.tanjab barat.

\section{Uji parsial (Uji t)}

Uji t atau secara parsial pada dasarnya digunakan untuk menunjukkan ada atau tidaknya pengaruh variabel bebas yaitu curahan jam kerja, pendidikan, usia dan luas lahan secara individual terhadap variabel terikat yaitu pendapatan. Untuk melihat hasil uji t atau secara parsial dapat dilihat pada tabel berikut:

Tabel 9. Uji t

\begin{tabular}{lccc}
\hline \multicolumn{1}{c}{ Variable } & t-hitung & t-Tabel(5\%) & Kesimpulan \\
\hline Curahan jam kerja & 0.552502 & 2.001 & Tidak Signifikan \\
Pendidikan & 2.467 .224 & 2.001 & Signifikan \\
Usia & -1.086 .758 & 2.001 & Tidak Signifikan \\
Luas lahan & 3.586 .220 & 2.001 & Signifikan \\
\hline
\end{tabular}

Sumber: Data diolah 2019

Dari Tabel 9 dapat dilihat nilai dalam uji $\mathrm{t}$ ditentukan menggunakan tabel distribusi normal dengan tingkat signifikan 5\% dan derajat kebebasan dengan rumus (a/2;n-k-1) dan didapat $\mathrm{t}$ tabel sebesar 2.001. Nilai thitung untuk variabel curahan jam kerja sebesar 0,552502 nilai probabilitas 0.5828 lebih kecil dari tabel sebesar 2.001 dengan tingkat signifikansi $0,05 \%$, maka Ho diterima dan Ha ditolak. hal ini berarti curahan jam kerja memiliki pengaruh yang tidak signifikan terhadap pendapatan rumah tangga miskin di Desa Semau Kecamatan Bram Itam Kabupaten Tanjab Barat.

Nilai thitung untuk varibel pendidikan sebesar 2.467224 dengan probabilitas sebesar 0.0166 lebih besar dari $t_{\text {tabel }}$ sebesar 2.001, dengan tingkat signifikan 5\%, maka Ho ditolak dan $\mathrm{Ha}$ diterima. Hal ini berarti pendidikan memiliki berpegaruh yang signifikan terhadap pendapatan rumah tangga miskin di Desa Semau Kecamatan Bram Itam Kabupaten Tanjab Barat.

Nilai thitung untuk variabel usia sebesar -1.086758 dengan probabilitas sebesar 0.2817 lebih kecil dari $t_{\text {tabel }}$ sebesar 2.001, dengan tingkat signifikan 5\%, maka Ho diterima dan Ha ditolak. Hal ini berarti usia memiliki berpengaruh yang tidak signifikan terhadap pendapatan rumah tangga miskin di Desa Semau Kecamatan Bram Itam Kabupaten Tanjab Barat.

Nilai thitung untuk variabel luas lahan sebesar 3.586220 dengan probabilitas sebesar 0.0007 lebih besar dari tabel sebesar 2.001, dengan tingkat signifikan 5\%, maka Ho diterima dan Ha ditolak. Hal ini berarti luas lahan memiliki berpengaruh yang signifikan terhadap pendapatan rumah tangga miskin di Desa Semau Kecamatan Bram Itam Kabupaten Tanjab Barat.

\section{Koefisien determinasi $\left(\mathbf{R}^{2}\right)$}

Koefisien determinasi $\left(\mathrm{R}^{2}\right)$ menunjukkan nilai 0.504353 , artinya 50,43\% pendapatan rumah tangga miskin desa semau kec.bram itam kab.tanjab barat dijelaskan oleh curah jam kerja, pendidikan, usia, luas lahan 49,57\% dipengaruhi oleh variabel lain diluar curahan jam kerja,pendidikan, usia, dan luas lahan. 


\section{Uji normalitas}

Uji normalitas bertujuan untuk menguji residual model regresi yang dibuat apakah berdistribusi normal atau tidak. Model regresi yang baik adalah yang memiliki distribusi normal atau mendekati normal, terpenuhi atau tidaknya uji normalitas dapat diuji dengan melakukan uji statistik Jerque-Bera.

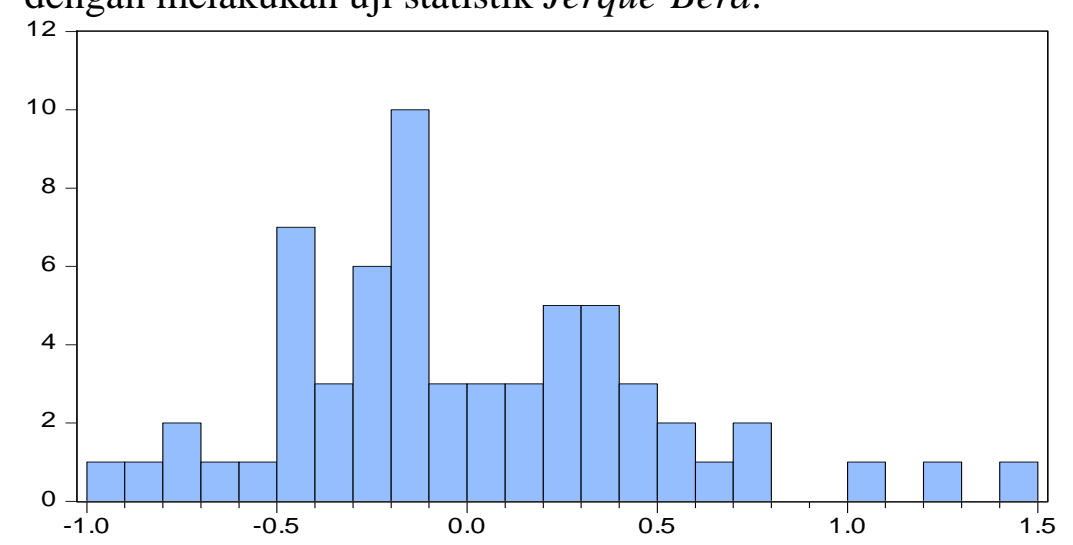

\begin{tabular}{|lc}
\hline \multicolumn{2}{l}{ Series: Residuals } \\
Sample 1 62 \\
\multicolumn{2}{|l}{ Observations 62} \\
Mean & $1.04 \mathrm{e}-16$ \\
Median & -0.115020 \\
Maximum & 1.445357 \\
Minimum & -0.926387 \\
Std. Dev. & 0.484026 \\
Skewness & 0.731484 \\
Kurtosis & 3.636949 \\
& \\
Jarque-Bera & 6.577114 \\
Probability & 0.037308 \\
\hline
\end{tabular}

Sumber: Data Diolah, 2019

Gambar 1. Uji normalitas

Berdasarkan Gambar.1 diatas besarnya nilai Jarque-Bera menunjukkan bahwa 6.577114 nilai probabilitas nilai $0.037308<0,05 \%$ maka uji menyatakan bahwa berdistribusi mendekati normal.

\section{Uji asumsi klasik}

\section{Uji multikolineritas}

Uji multikonlineritas digunakan untuk mengetahui apakah terdapat hubungan yang kuat diantara variabel bebas dideteksi menggunakan Varianceinflastion Factor(VIF). Dapat dilihat pada tabel berikut:

Tabel 10. Uji multikolineritas

\begin{tabular}{lccc}
\hline \multicolumn{1}{c}{ Variable } & $\begin{array}{c}\text { Coefficient } \\
\text { Variance }\end{array}$ & $\begin{array}{c}\text { Uncentered } \\
\text { VIF }\end{array}$ & $\begin{array}{c}\text { Centered } \\
\text { VIF }\end{array}$ \\
\hline C & 0.918861 & 227.2213 & NA \\
Curahan jam kerja & 0.000111 & 85.29503 & 3.140256 \\
Pendidikan & 0.000493 & 7.260845 & 1.662396 \\
Usia & $6.41 \mathrm{E}-05$ & 49.65010 & 3.508346 \\
Luas lahan & 0.130935 & 2.346058 & 1.174222 \\
\hline
\end{tabular}

Sumber : Data diolah, 2019

Pada Tabel.10 dapat dilihat hasil pengujian Varianceinflation Factor(VIF) bahwa nilai Centered VIF variabel curahan jam kerja sebesar 3,1402, variabel pendidikan sebesar 1,6623, usia sebesar 3,5083, luas lahan 1,1742, semua nilai tersebut kurang dari 10, maka dapat dinyatakan bahwa tidak terdapat masalah multikolinieritas pada model prediksi.

\section{Uji autokorelasi}

Uji autokorelasi digunakan untuk memenuhi ada atau tidaknya penyimpangan asumsi klasik autokorelasi, yaitu korelasi yang terjadi antara residual pada satu pengamatan dengan pengamatan lain pada model regresi. Metode pengujian yang sering digunakan adalah dengan uji Breusch-Godfrey Serial Correlation LM Test. 
Tabel 11. Hasil uji autokorelasi

\section{Breusch-Godfrey Serial Correlation LM Test:}

\begin{tabular}{llll} 
F-statistic & 2.160764 & Prob. F(2,55) & 0.1249 \\
Obs*R-squared & 4.516653 & Prob. Chi-Square(2) & 0.1045 \\
\hline
\end{tabular}

Sumber : Data diolah, 2019

Berdasarkan Tabel.11 diatas menunjukan tabel autokorelasi dengan menggunakan Breusch-godfrey tes(BG)Dan berdasarkan uji BG dapat dijelskan bahwa nilai probabilitas chi-square(2) menunjukan nilai 0.1045 . berdasarkan kreteria nilai 0.1045 hampir telah mendekati tingkat signifikasi sebesar $(\alpha=0,10)$ maka uji diatas terdapat masalah autokorelasi.

\section{Uji heterokedestisitas}

Uji heterokedestisitas digunakan untuk melihat apakah ada ketidaksamaan varian dari residuel untuk pengamatan pada model regresi berganda. Apabila asumsi heterokedestisitas tidak terpenuhi maka model regresi dinyatakan tidak valid. Pada tabel sebagai berikut:

Tabel 12. Hasil uji heterokedestisitas

\begin{tabular}{llll}
\hline Heteroskedasticity Test: Glejser & & & \\
\hline \hline & & & \\
F-statistic & 0.528035 & Prob. F(4,57) & 0.7156 \\
Obs*R-squared & 2.215326 & Prob. Chi-Square(4) & 0.6962 \\
Scaled explained SS & 2.034649 & Prob. Chi-Square(4) & 0.7294 \\
\hline
\end{tabular}

Sumber : Data diolah, 2019

Berdasarkan Tabel.12 diatas menunjukan tabel uji heterokedastisitas dengan menggunakan uji glejser heterokedasticity dari hasil tabel diatas menunjukan bahwa nilai $\mathrm{p}$ value yang ditunjukan dengan prob. Chi-square(4) pada Obs*R-Squared yaitu sebesar 2.215326 oleh nilai $\mathrm{p}$ value $0.6962>0.05$ maka yang berarti model bersifat homoskedestisitas atau dengan kata lain tidak ada masalah asumsi non heteroskadestisitas.

\section{KESIMPULAN DAN SARAN}

\section{Kesimpulan}

Rumah tangga miskin menurut karekteristik sosial ekonomi yang berada di Desa Semau kecamatan Bram Itam, rata-rata didominasi oleh kelompok curah jam kerja 180230 jam yaitu sebesar $61.29 \%$, tigkat pendidikan tidak tamat SD 43.5\%, tingkat Usia/umur rata-rata $>50$ tahun yaitu sebesar $53.2 \%$, luas lahan 0,10-50 sebesar $64.5 \%$. Rata-rata pendapatan daerah dari Rp 500.000 - Rp 800.000 sebesar 41.9\%, Sementara dari hasil regresi Variabel curah jam kerja, usia memiliki pengaruh yang tidak signifikan dan pendidikan, luas lahan berpengaruh signifikan terhadap pendapatan rumah tangga miskin di Desa Semau kecamatan Bram Itam. Sedngkan uji t atau secara parsial variabel curah jam kerja, pendidikan dan usia tidak memiliki pengaruh yang signifikan sedangkan luas lahan memiliki pengaruh yang signifikan terhadap pendapatan rumah tangga miskin di Desa Semau kecamatan Bram Itam.

\section{Saran}

Untuk rumah tangga miskin di Desa Semau kecamatan Bram Itam pelu adanya penghematan dalam keperluan yang dilakukan dalam rumah tangga, pengeluaran yang 
dilakukan haruslah yang dibutuh kan dalam rumah tangga karena yang dibutuhkan dalam rumah tangga sangatlah penting meskipun keinginan untuk kebutuhan yang lainlainnya. Dari pemeritahan itu juga harus mensurvei yang mana yang dikatakan termaksud dalam rumah tangga miskin dan dalam memberikan bantuan pemerintah belum tepat sasaran benar-benar untuk rumah tangga miskin.

\section{DAFTAR FUSTAKA}

Arif Takdir, Abubakar Hamzah,dan Mohd. Nur Syechalad (2013): Analisis kemiskinan rumah tangga berdasarkan karakteristik sosial ekonomi di Kabupaten Aceh Barat Daya. Jurnal Ilmu Ekonomi Magister Ilmu Ekonomi Pascasarjana Universyitas Syiah Kuala Banda Aceh. 1(4), 67-75.

B Bahrun, S Syaparuddin, H Hardiani. (2014).Analisis pendapatan dan pola pengeluaran rumah tangga miskin di Kabupaten Sarolangun, Jurnal Perspektif Pembiayaan dan Pembangunan Daerah 2 (1), 1-8

Badan Pusat Statistik, (2016). Kabupaten Tanjung Jabung Barat Dalam Angka. BPS: Tanjab barat.

Badan Pusat Statistik, (2017). Kemiskinan Indonesia. BPS: Jakarta.

Faturahman, Imron. (2009). Analisis faktor-faktor yang mempengaruhi kemiskinan di Kecamatan Jelbuk Kabupaten Jember.Skripsi. Jurusan Ilmu Ekonomi Studi Pembangunan Fakultas Ekonomi Universitas Jember.Jawa Timu

N Nopriansyah, J Junaidi, E Umiyati . (2015). Determinan kemiskinan rumah tangga di Provinsi Jambi, Jurnal Perspektif Pembiayaan dan Pembangunan Daerah 2 (3), 119-128

Prasetyo, Adit. (2010). Analisis Faktor - faktor yang mempengaruhi tingkat kemiskinan. Skripsi Fakultas Ekonomi Universitas Diponegoro : Semarang.

Rahmawati, Y.I. (2006). Analisis faktor-faktor yang mempengaruhi kemiskinan rumah tangga di Kabupaten Pacitan Provinsi Jawa Timur. Skripsi. Program Studi Ekonomi Pertanian dan Sumberdaya. Fakultas Pertanian. Institut Pertanian Bogor. Bogor.

Sugiyono. (2013). Metode penelitian pendidikan (pendekatan kuantitatif, kualitatif, dan $R \& D)$. Alfabeta: Bandung.

Undang-Undang No.11 tahun 2009 Tentang kesejahteraan sosial.

Yufi Halimah,Sa'diyah dan Fitrie Arianti (2012) : Analisis kemiskinan rumah tangga melalui faktor-faktor yang mempengaruhinya di Kecamatan Tugu Kota Semarang, Journal of Accounting Jurusan IESP Fakultas Ekonomika dan Bisnis Universitas Diponegoro. 1(1), 1-11.

Z Zamzami, D Hastuti. (2018). Determinan penerimaan daerah dan pertumbuhan ekonomi terhadap pengembangan ekonomi kreatif di Provinsi Jambi, Jurnal Paradigma Ekonomika, 13 (1), 37-45 